\title{
Death Row: \\ An Existence of \\ Non-Existence
}

\section{János Szabó}

The subject of the death penalty is a hot issue at this time. The reasons are many, and not one of them makes any sense in the way our society has been brought up over the years. I have been on death row since 1979 waiting for the state to make up its collective mind as to whether it is going to execute me or not. Not that I am fearful of death, because I am not, since with the birth of each person into this world, $\mathrm{s} /$ he is ultimately born dying. There are many reasons why I am mad, though, about society, and their so-called understanding, and, also, about what is called our judicial system.

Is it right for one man to request that the state take his life, knowing that his actions are going to affect each and every man on death row throughout the state of Illinois? Is it right, such as in my case, for the state to grant another person immunity from all self-incrimination, as long as the person being granted immunity takes the stand against the defendant? Neither of the above questions is right no matter how one may choose to look at it, since a life is hanging in the balance.

I have been sitting on death row, as I said earlier, since 1979. I could just sit here and waste my time by doing nothing, but I chose not to do so. While in society going to school I couldn't care less about learning any of what they wanted to teach. Since being on death row, I must say that my mind has changed quite a bit in many ways. In society I didn't read books because nothing interested me. I have over the years of being in prison, more than likely read over two hundred books on European history. I have become a self-taught man in many ways.

Reprinted with kind permission from The Critical Criminologist, Volume 2, Number 3, Autumn, 1990:15-16. 
Sure, death row is not vacation. But being on death row has given me the opportunity I needed to get back in touch with myself. It has given me the time I needed to look into my soul and find why I had such a volatile temper, when I knew for myself that I had a heart that would reach out to help anybody.

I won't make any excuses for myself, but I will say that I feel that if it were not for the fact that I was a heavy user of narcotics since the age of nine, until the day I was arrested, that I more than likely would not be in prison on death row at this time, or, for that matter, at any time during my life.

Being a resident of death row for over eleven years has been one hell of an eye-opener in many respects. It has shown me just how easy it is for our very own government to brain-wash people into voting this way or that, and into believing what they choose to release to society. What is all this rhetoric about a kinder/gentler nation, when in the same breath this very same government of the U.S. is pushing the issue of the death penalty?

I know that I am not a perfect human being, but neither are any of you that may happen to be reading this article. Not one of you can go through life and say you never did anything wrong. A person that does wrong ultimately has to turn his life around in order to learn. In other words, life to me is nothing but a learning process. And if no person had ever done anything wrong, or ever made a mistake, nobody would ever grow in life or make progress to move into the next stage of development.

Prison has taught me that I can change, that I can make it through life without the use or need of drugs. It has taught me that I am a strong-willed man that will not give up the fight until my last dying breath. But I have also learned that prisons are no longer the buildings where one can be rehabilitated and returned to society a better person for the time done. What prisons have now become are nothing short of P.O.W. camps. We, the men of death row and prison in general, are fighting for our lives and the right to return to society and become useful to our country. But how can this be accomplished when a man in prison is either going to be put to death, or he is going to have to do his time without the opportunity of bettering himself enough to fit back 
Journal of Prisoners on Prisons, Vol. 3, No. 1/2, Spring, 1991.

into your so-called society where skills are in the greatest demand as never before?

Doing time in prison is bad enough, but doing time in prison where you are not required to take courses to better yourself is even more outlandish. And to have to sit on death row waiting to have your life taken from you by a so-called government of a kinder/gentler nation is just out and out ignorant. And think of this if you will: what type of society will America have when more and more people start getting out of prison without the skills to match the rest of society? There are already over one million people that belong to the homeless class, and about the same amount or more that do not carry the skills to make it in society in this day and age. Without prisons being used to rehabilitate as they were intended to do, society is doing nothing but taking part in what may soon become another Third World. The difference is that this Third World will be right here in America.

Yes, prison has given me much time to think about the problem of America and the world. And what I see as the main cause is a government that cares more for itself than the people in society. If the American government did care about society, or even about the people in prison, they would not allow district attorneys to play political games with the lives of people, one of whom may be any of you in the near future.

The game the American government is playing with the lives and minds of the American society is a very diabolical one that you are all falling into in one form or another. America says in one breath to the USSR not to use the death penalty, and in the next breath it is pushing to have the death penalty used more widely here in the U.S. It sends money to other countries to help them, yet right here in this country help is needed for the homeless. What kind of games is it playing with U.S. society?

I'm not telling you that there are no screw-ups in society. What I am saying is that people need to be given a second chance at life and freedom. You can't just warehouse them away or kill them because you say you are embarrassed. People must help people; that is what makes us human. 
Being in prison has not been the hell one would think it to be. For me it has been a means by which to learn and grow. Although I will say to you that it was not always this way. For the first year or so death row was a living hell, an existence of non-existence. I grew old as society made progress and took a part in bringing peace to Europe. Yet, at the same time I made my mind up to make progress within my own mind and life.

I don't wish to give you the false impression that one does not suffer while being on death row, because one does. With each new day comes a new test of one's will and faith. One has to make up his/her mind whether or not s/he is going to accept that $\mathrm{s} /$ he may be put to death. I myself have found peace within, even though people like you in society may look down on me. This is supposed to be a nation of forgiving people. Boy, that is one bottom of the barrel lie. What I am trying to come to terms with is that I may never get the chance to visit with my folks again in the wide open air of society. That I may never get the chance to see my nephew and niece, young people that I've yet to set eyes upon. But what bothers me the most is that I may never get the chance to prove to a society as you that I not only can be but have already been rehabilitated.

Instead, I get to sit back and read to help my mind grow, even though we no longer have access to an outside library as we once did. I get to watch as another day passes by without my presence in society. I get to watch as the guards pass by the cells, knowing what is on their minds, that they would like to be the ones to stick the needles in our arms and watch as life is drained from our body. I have been dead already for over eleven years!

Being in prison has brought out the seriousness in me. What time calls more for being serious than right now, the time when my life is on the line? There is nothing like sitting in a cell not knowing when your time will be up. Whether it will be today or tomorrow. Not knowing whether you will be put to death or given an amount of time to do what even Methuselah could not dream of doing. Sure, I'm more serious about life now. I'm more serious about everything pertaining to life. And in obtaining 
this seriousness, I have also obtained a better perspective on life. But what $I$ have not yet been able to obtain is the open-hearted forgiveness from a society that has done as much wrong in its daily living as any person you pick from a prison.

Tell me what is fair, the government punishing a person by putting them in prison or maybe to death, or society punishing a person by not giving her/him a chance to prove s/he can be rehabilitated? Is it fair for a judge to give out a sentence of a six hundred million dollar fine and three years to a person that has affected the lives of maybe one million or more people? Or, is it fair for a judge to sentence a person to ninety-nine years in prison for stealing a pack of cigarettes? Neither is fair when you have a judicial system that is as arbitrary as ours is.

Thinking and learning is what I do with my time here on death row. Other than this, I sit and wait for the day that may just come around tomorrow and end a life that I have turned around myself. A life that I am proud of. A life that I want to better with each coming day. A life that may end tomorrow in this existence of non-existence. 
